\title{
Fimbriation and P-antigen Recognition of Escherichia coli Strains Harbouring Mutated Recombinant Plasmids Encoding Fimbrial Adhesins of the Uropathogenic $E$. coli Strain KS71
}

\author{
By MIKAEL RHEN, ${ }^{*}$ JUKKA TENHUNEN, ${ }^{1}$ VUOKKO VÄISÄNEN- \\ RHEN, ${ }^{1}$ AULI PERE, ${ }^{1}$ MONICA BÅA ${ }^{2}$ AND TIMO K. KORHONEN ${ }^{1}$ \\ ${ }^{1}$ Department of General Microbiology, University of Helsinki, Mannerheimintie 172, \\ 00280 Helsinki 28, Finland \\ ${ }^{2}$ Department of Microbiology, University of Umeå, $S 90187$ Umeå, Sweden
}

(Received 20 March 1985; revised 24 July 1985)

Deletion mutants of recombinant plasmids encoding the KS71B fimbrial antigens of the
uropathogenic Escherichia coli strain KS71 $(\mathrm{O} 4: \mathrm{K} 12)$ were constructed. The effects of these
mutations were tested by transforming the mutated plasmids into non-fimbriated E. coli HB 101
cells and testing the transformants for fimbriation and haemagglutination. A deletion
transcriptionally upstream from the fimbrial subunit gene increased the expression of KS71B
fimbriae. Deletion of the fimbrial subunit gene resulted in non-fimbriated but haemagglutinat-
ing transformants, whereas a deletion $6 \mathrm{~kb}$ transcriptionally downstream from the subunit gene
resulted in non-haemagglutinating but fimbriate transformants, indicating that fimbriation and
haemagglutination were genetically separable. We also present evidence suggesting that the
fimbrillin and haemagglutinin are physically associated in the wild-type KS71 strain.

\section{INTRODUCTION}

The fimbriae form, beside the $\mathrm{K}, \mathrm{O}$ and $\mathrm{H}$ antigens; a fourth major group of surface antigens in Escherichia coli (Duguid et al., 1955; Ørskov et al., 1982). They are filamentous surface appendages built up of hundreds of proteinaceous subunits (Brinton, 1965). Many different types of fimbriae, distinguishable both by biochemical and serological means, occur on $E$. coli (Korhonen et al., 1985a). Most common is the mannoside-binding type 1 fimbria; other fimbriae occur more restrictedly on strains associated with infectious diseases, e.g. the K88, K99, CFA/I and CFA/II fimbrial antigens of enterotoxigenic E. coli (Gaastra \& de Graaf, 1982) and the P-fimbriae characteristic of human pyelonephritogenic $E$. coli strains (Korhonen et al., 1982; Svanborg Eden \& Hansson, 1978; Väisänen et al., 1981). The latter contribute to bacterial virulence by promoting adhesion to the blood-group-P-antigens on host cell membranes (Korhonen et al., 1980a).

Our analysis of $E$. coli strains causing human childhood pyelonephritis (Rhen et al., 1983a; Väisänen-Rhen et al., 1984) and neonatal septicaemia (Korhonen et al., 1985b) has shown that most of the pathogenic strains can express many fimbrial antigens. The different fimbrial types occur, at a given time, mostly on separate cells and show a rapid phase variation (Rhen et al., $1983 c$; Nowicki et al., 1984, 1985).

To study the molecular basis of fimbrial phase variation we have recently cloned the fimbrial genes from our pyelonephritogenic, multifimbriated model strain, E. coli KS71 (O4:K12) (Rhen et al., 1983a). Each of the four types of fimbriae (termed KS71 A, KS71B, KS71C and KS71D) is encoded by a separate set of genes (Rhen, 1985; M. Rhen, unpublished). KS71A and KS71 B are P-fimbriae, KS71C appears to be non-haemagglutinating and KS71D corresponds to the type 1 fimbriae. Serological analyses of the phase variation of KS71 fimbriae have recently been described (Rhen et al., 1983c; Nowicki et al., 1984). 
In this communication we describe three types of mutations within the cloned gene cluster encoding KS71B fimbriae; (i) deletions affecting the level of fimbrial expression, (ii) deletions abolishing fimbrial expression but not haemagglutination, and (iii) deletions abolishing haemagglutination but not the expression of fimbriae. We also present evidence indicating that the KS71B fimbriae and the haemagglutinin are physically associated in the wild-type $E$. coli KS71 strain.

\section{METHODS}

Bacterial strains, phages and plasmids. E. coli $\mathrm{HB} 101$ cells (Leu- $\mathrm{Pro}^{-} \mathrm{HsdS} \mathrm{S}^{-} \mathrm{StrA}^{-} \mathrm{Thi}^{-} \mathrm{RecA}^{-}$) were grown for $16-18 \mathrm{~h}$ at $37^{\circ} \mathrm{C}$ in Luria broth or on Luria agar supplemented with $100 \mu \mathrm{g}$ ampicillin $\mathrm{ml}^{-1}$ (Wyeth Laboratories, USA) or with $20 \mu \mathrm{g}$ chloramphenicol $\mathrm{ml}^{-1}$ (Sigma). The phage M13 derivative mp9 (Messinger \& Vieira, 1982) was harboured in E. coli JM101 ( $\mathrm{Lac}^{-}$FtraD36 $\mathrm{Thi}^{-}$Pro $^{-}$). The cloning vectors pBR322 and pACYC184 were those described by Bolivar et al. (1977) and Chang \& Cohen (1978). Recombinant plasmids pKTH3011, pKTH3019, pK TH3024, pK TH3025, pKTH3026, pKTH3026-1, pK TH3026-2, pK TH3026-3 and pK TH3026-4 were available from previous works (Rhen, 1985; Rhen et al., 1985a).

Cloning procedures and restriction mapping. Restriction endonucleases and $T_{4}$ DNA ligase obtained from Boehringer-Mannheim and Amersham were used under conditions recommended by Maniatis et al. (1982). Plasmid and phage DNA was isolated from cell lysates by ethidium bromide/caesium chloride equilibrium gradient centrifugation (Maniatis et al., 1982). For screening purposes the DNA was isolated by the alkaline lysis method of Birnboim \& Doly (1979). Ligated DNA and isolated plasmid and phage DNA were introduced into recipient strains by transformation of $\mathrm{CaCl}_{2}$-treated cells (Mandel \& Higa, 1970). Restriction mapping was done as described previously (Rhen, 1985).

Isolation of Tn1725 insertion mutants. The production and isolation of $\mathrm{Tn} 1725$ insertion mutants has been described previously (Altenbuchner et al., 1983). The mutant plasmids were used in double transformation experiments after removing the chloramphenicol resistance marker by a partial HindIII digestion.

DNA sequencing. The chain termination method of Sanger et al. (1977) was used, employing recombinant M13 DNA as template. Sequencing primer and DNA polymerase I Klenow fragment were purchased from BoehringerMannheim, and deoxyadenosine $\left[{ }^{35}\right.$ S $]$ thiotriphosphate from Amersham.

Preparation of Fab fragments. The antisera against E. coli KS71 ABC, KS71 A, KS71C and ER2B2 fimbriae have been characterized previously (Rhen et al., 1983a,c). Purified E. coli ER2B1 fimbriae were prepared by immune precipitation (Rhen et al., 1983a) and anti-ER2B1 was obtained by immunizing rabbits according to Korhonen $e t$ $a l .(1980 b)$. Fab fragments were prepared by papain treatment of immunoglobulin fractions isolated from these antisera (Porter, 1959). The activity of the Fab preparations was controlled in an enzyme linked immunosorbent assay employing $E$. coli $\mathrm{KS} 71 \mathrm{ABC}$ or ER2A1B1B2 fimbriae as solid phase antigen and alkaline phosphatase conjugated swine anti-rabbit IgG (Orion Diagnostica, Finland) (Rhen et al., 1983a).

Agglutination tests. The factor antisera against KS71A or KS71B fimbriae were those described previously (Rhen, 1985). Bacterial agglutination and serological quantification of fimbriae production were done according to Rhen et al. (1985a). Mannose-resistant haemagglutination and inhibition of haemagglutination were done as described previously (Rhen et al., 1983b).

Electron microscopy. Bacteria were negatively stained with $2 \%(\mathrm{w} / \mathrm{v})$ phosphotungstic acid in $0 \cdot 1 \mathrm{M}$-phosphate buffer (pH 6.5) and examined with a JEM-100B electron microscope operating at $80 \mathrm{kV}$. Electron micrographs were taken at the Department of Electron microscopy, University of Helsinki.

\section{RESULTS}

Sequencing of the 5'-end of the KS71B fimbrillin gene. The KS71B fimbrial subunit gene has previously been mapped within the $1.1 \mathrm{~kb}$ SmaI-ClaI fragment of pKTH3026 (Fig. 1a), which is a subclone of the KS71B-expressing recombinant plasmid pKTH3011 (Rhen et al., 1985a). The Bam HI-ClaI insert fragment of pK TH3026 was also cloned in the corresponding cloning sites of pBR322, giving the plasmid pKTH3030 (Fig. 1b). A Tn 1725 insertion derivative of pKTH3030, pKTH3030-1, was isolated that contained the insert within the $1 \cdot 1 \mathrm{~kb}$ SmaI-ClaI fragment (Fig. $1 b$ ). In contrast to pK TH3030, the transposon derivative pKTH3030-1 did not express KS71B when complemented with pKTH3024 (Table 1). pKTH3024 encodes KS71A fimbriae and can produce KS71B fimbriae if provided with the subunit gene (Rhen et al., $1985 a$ ).

A stretch of 444 nucleotides was sequenced from the EcoRI sites created by $\operatorname{Tn} 1725$ in pKTH3030-1. The DNA sequence obtained contained the region encoding the 21 amino acid 
(a)

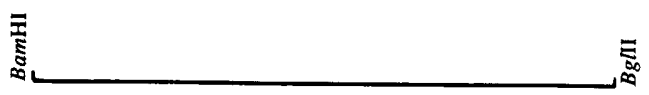

pKTH3019-12
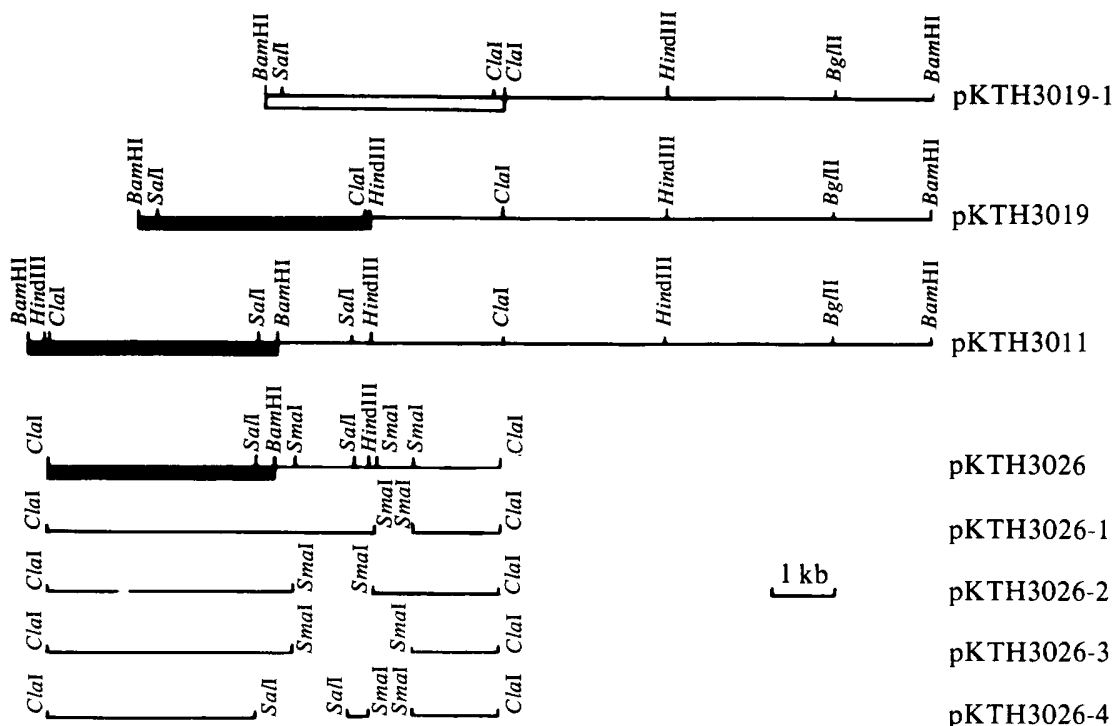

pKTH3026

pKTH3026-1

pKTH3026-2

pKTH3026-3

pKTH3026-4

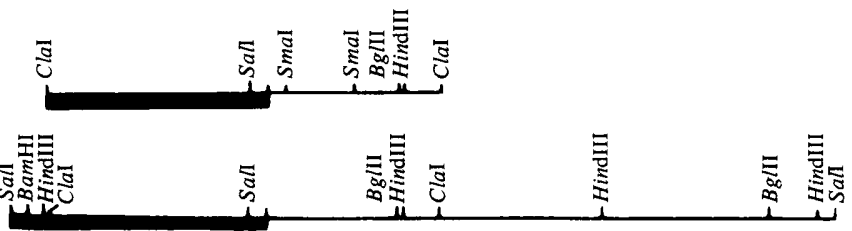

pKTH3025

pKTH3024

(b)

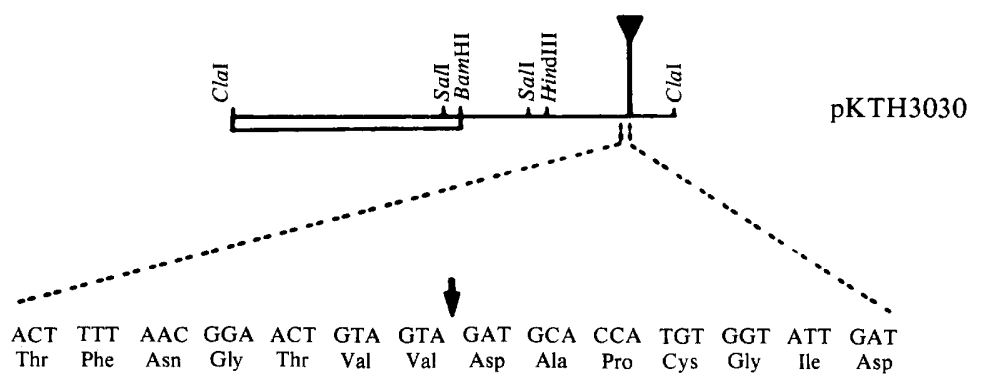

Fig. 1. (a) Restriction endonuclease maps of recombinant plasmids encoding KS71A(pKTH3024) or KS71B(pKTH3011) fimbriae and of their subclones. The thick lines are DNA of the cloning vectors pBR322 ( $\square$ ) and pACYC184 (ש). Thin lines with restriction endonuclease cleavage sites marked indicate insert DNA. The deletion derivatives of pKTH3019 and pKTH3026 are shown as thin lines, indicating the DNA present in the corresponding plasmid. (b) The position of the $\mathrm{Tn} 1725$ insertion present in pKTH3030-1 is indicated by the arrow on the map of $\mathrm{pKTH} 3030$; the insertion point within the KS71B fimbrial subunit gene is shown underneath (only a part of the sequence is shown).

signal sequence and the $113 \mathrm{NH}_{2}$-terminal amino acids of the $\mathrm{F}_{2}$ fimbrial gene (Van Die \& Bergmans, 1984). The 42 nucleotide stretch preceding the signal sequence initiation codon was the same as that preceding the $\mathrm{F}_{2}, \mathrm{KS} 71 \mathrm{~A}$ and papA genes (Båga et al., 1984; Rhen et al., 1985 b; Van Die \& Bergmans, 1984). Our Tn 1725 insertion was situated after the codon encoding the 18th $\mathrm{NH}_{2}$-terminal amino acid of the mature fimbrillin (Fig. $1 b$ ). A stretch of 280 nucleotides 
Table 1. Agglutination properties of recombinant E. coli HB101 strains

\begin{tabular}{|c|c|c|c|c|}
\hline \multirow[b]{2}{*}{$\begin{array}{l}\text { Plasmid(s) in } \\
\text { E. coli } \mathrm{HB} 101\end{array}$} & \multicolumn{2}{|c|}{ Agglutination with:* } & \multirow[b]{2}{*}{ MR-HA $†$} & \multirow{2}{*}{$\begin{array}{l}\text { Agglutination titre } \\
\text { of absorbed anti- } \\
\text { KS7IB serum } \neq\end{array}$} \\
\hline & $\begin{array}{c}\text { anti-KS71A } \\
\text { serum }\end{array}$ & $\begin{array}{c}\text { anti-KS71B } \\
\text { serum }\end{array}$ & & \\
\hline pK TH3030,pK TH3024 & +++ & ++ & + & 20 \\
\hline pK TH3030-1,pK TH 3024 & +++ & - & + & 2560 \\
\hline pKTH3026,pK TH3019-1 & - & + & + & 2560 \\
\hline pK TH3026-1,pK TH3019-1 & - & + & + & 1280 \\
\hline pK TH $3026-2$, pK TH $3019-1$ & - & + & + & 2560 \\
\hline pK TH3026-3,pK TH3019-1 & - & - & + & 2560 \\
\hline pKTH3026-4,pK TH3019-1 & - & ++ & + & 320 \\
\hline pKTH3019-1 & - & - & + & 2560 \\
\hline pKTH3019-12 & - & - & - & 2560 \\
\hline pK TH3025,pK TH3019-1 & +++ & - & + & 1280 \\
\hline pK TH3025,pK TH3019-12 & +++ & - & - & 1280 \\
\hline pK TH3026-4,pK ТН $3019-12$ & - & ++ & - & 640 \\
\hline
\end{tabular}

was sequenced from the region situated at the left of the ClaI site in pKTH3030 (Fig. $1 b$ ). This sequence included a region corresponding to the six last amino acid codons of the $\mathrm{F} 7_{2}, \mathrm{KS} 71 \mathrm{~A}$ and papA genes. The 259 base pair sequence situated between the stop codon and the ClaI site of pK TH3030 was identical to the corresponding region of the recombinant plasmid encoding the KS71 A fimbrillin (Rhen et al., 1985b). We therefore conclude that the KS71B fimbrillin gene starts $0.8 \mathrm{~kb}$ to the left of the Cla I site in pKTH3030 (Fig. $1 b$ ) and that the transcription proceeds from left to right.

Deletions affecting the level of KS7IB production. The expression of KS71B fimbriae by pKTH3011 or pK TH3019 is low in E. coli HB101 (Rhen, 1985). Furthermore, only 3 to $5 \%$ of the pKTH3011 or pK TH3019 transformants are strongly agglutinable with anti-KS71B serum. We therefore tested the pKTH3011 subclones pKTH3026, pKTH3026-1, pKTH3026-2, pKTH3026-3 and pKTH3026-4 (Fig. 1a) for expression of KS71B when complemented with pKTH3019-1. pKTH3019-1 was obtained by transferring the $8 \mathrm{~kb}$ Cla I-BamHI fragment of pKTH3019, after fill in of the ClaI site, to the EcoRV-BamHI site of pBR322 (Fig. 1a). The expression of KS71B was low with pKTH3026 and pKTH3026-1, slightly stronger with pK TH3026-2 and negative with pK TH3026-3 (Table 1). A significantly stronger expression of KS71B was obtained with pKTH3026-4 (Table 1) and all the double transformants tested $(50 / 50)$ strongly reacted with anti-KS71B serum. The reason for the changed pattern of fimbrial expression observed when using pK TH3026.4 is not known; however, E. coli HB101 harbouring pKTH3026-2 or pKTH3026-4 together with pKTH3019-1 forms a better source of KS71B fimbriae than the ancestral clone.

The KS71B fimbrillin gene is not essential for haemagglutination. E. coli $\mathrm{HB} 101$ cells harbouring pKTH3019-1 did not react with anti-KS71B serum but caused a P-blood-group-antigen-specific haemagglutination, even though the KS71B fimbrillin gene is missing in pKTH3019-1 (Table 1). These recombinant cells also appeared non-fimbriated in the electron microscope (data not shown). Haemagglutination of $\mathrm{HB} 101$ cells was abolished if the $1.6 \mathrm{~kb} \mathrm{Bg} / \mathrm{II}-\mathrm{BamHI}$ fragment of pKTH3019-1 was deleted (Table 1; the deleted pKTH3019-1 derivative was termed 


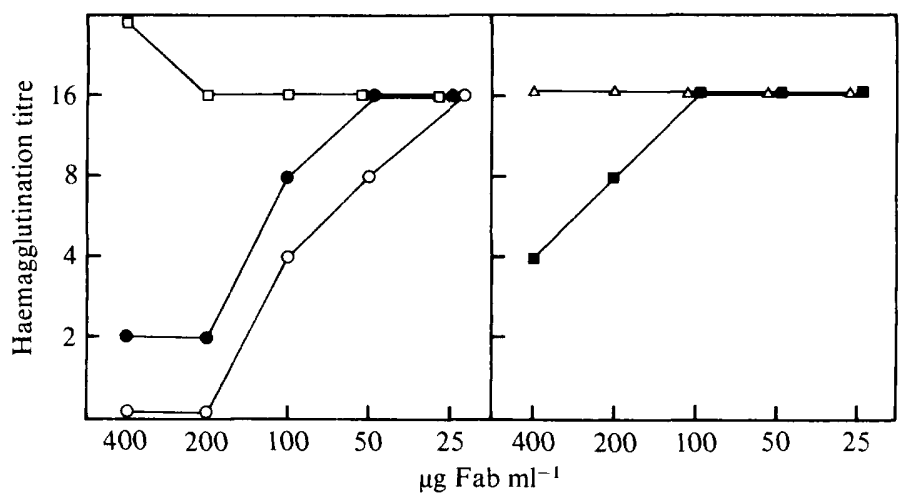

Fig. 2. Haemagglutination titres of $E$. coli $\mathrm{HB} 101$ cells harbouring pKTH3019-1 in the presence of various concentrations of anti-fimbriae Fab fragments. O, Anti-KS71ABC Fab; onti-KS71A Fab; $\square$, anti-KS71C Fab;, anti-ER2B1 Fab; $\triangle$, anti-ER2B2 Fab.

pKTH3019-12). pKTH3025 or pKTH3026 (Fig. 1 a) expressed KS71A or KS71B fimbriae when complemented with pKTH3019-1 or pKTH3019-12 as judged by agglutination in antiserum (Table 1) and by electron microscopy (data not shown). These strains were haemagglutinating if they contained pKTH3019-1 but not if they contained pKTH3019-12, indicating that fimbriation as such did not result in haemagglutination.

Inhibition of haemagglutination directed by pKTH3019-1 by Fab fragments. Fab fragments were prepared from antisera raised against KS71ABC, KS71A and KS71C fimbriae and from antisera against $\mathrm{P}$ and type $\mathrm{C}$ fimbriae of $E$. coli strain ER2 (O4:K12). The ability of these Fab fragments to inhibit haemagglutination by $E$. coli $\mathrm{HB} 101$ harbouring pKTH3019-1 is shown in Fig. 2. Fab fragments against P-fimbriae (KS71ABC, KS71A and ER2B1) inhibited the haemagglutination in a dose-dependent fashion, whereas Fab fragments against the nonhaemagglutinating fimbriae (KS71C and ER2B2) were non-inhibitory.

\section{DISCUSSION}

The genes for various virulence-associated fimbriae have recently been cloned and characterized. These include the genes for mannose-binding and P-fimbriae of uropathogenic $E$. coli (Clegg \& Pierce, 1983; Normark et al., 1983; Orndorff \& Falkow, 1984; Van Die et al., 1984) as well as the genes for the K88 (Mooi et al., 1981) and the K99 (de Graaf et al., 1984) fimbriae of enterotoxigenic $E$. coli. A common property of all these genes is that they occur as multigene clusters which contain, in addition to the fimbrillin gene, genes for assembly and transport functions. So far, only in studies with the pap pilus operon could the fimbrillin gene be inactivated by mutation without loss of receptor binding activity (Lindberg et al., 1984; Norgren et al., 1984). Possibly, there are two groups of fimbriae; those whose fimbrial subunits possess binding properties and those that need additional components for action.

In this communication we have shown that fimbriation and haemagglutination are genetically separable properties of recombinant strains expressing KS71B fimbriae (Table 1). This probably also holds for the KS71A fimbriae, as non-haemagglutinating fimbriate recombinant strains were obtained (Table 1).

We have previously shown that Fab fragments specific for P-fimbriae inhibited haemagglutination caused by the wild-type KS71 strain (Rhen et al., 1983a). In this study we show that the same Fab fragments inhibit haemagglutination caused by a non-fimbriated recombinant strain (Fig. 2). This inhibition can result from an immunological cross-reaction between P-fimbriae and the haemagglutinin or be due to the presence of anti-haemagglutinin antibodies in the anti-P-fimbriae sera. If the first assumption is correct, then the haemagglutinin could be a minor, fimbrial-like protein present in amounts too low to be seen on Coomassie blue 
stained acrylamide gels (Rhen et al., 1983b). If the second assumption is correct, then the haemagglutinin must be associated with P-fimbrial filaments in wild-type $E$. coli KS71. It should be noted that the anti-KS71A and anti-KS71C sera were obtained with antigens purified from the same fimbrial extract (Rhen et al., 1983a) and that Fab fragments specific for KS71C fimbriae did not inhibit haemagglutination (Fig. 2; Rhen et al., 1983a). Hence, the adhesin in the wild-type strain was somehow co-purified with the KS71A but not with the KS71C fimbriae.

It is possible to fractionate distinct subpopulations from E. coli KS71 cultures on the basis of either the binding specificities or the serological properties of the KS71 fimbriae (Rhen et al., $1983 c$ ). Similar findings have been obtained with $E$. coli 3040 , a strain possessing both $\mathrm{S}$ and type 1 fimbriae (Nowicki et al., 1985). These findings also predict that the binding specificity and certain fimbrial subunits are physically associated or that they are co-expressed in the same cells.

The presence of anti-haemagglutinin antibodies in P-fimbriae antisera explains the ability of these antisera to inhibit adhesion of $E$. coli to uroepithelial cells (Korhonen et al., 1981; Rhen et $a l ., 1983 a$ ) and supports the idea of using purified P-fimbriae as a vaccine against pyelonephritis (Roberts et al., 1984).

This study was supported by the Academy of Finland.

\section{REFERENCES}

Altenbuchner, J., Schmid, K. \& Scmitt, R. (1983). Tn1721-encoded tetracycline resistance: mapping of structural and regulatory genes mediating resistance. Journal of Bacteriology 153, 116-123.

BR̊ga, M., Normark, S., Hardy, J., O'Hanley, P., LARK, D., OlsSON, O., SchOOLNIK, G. \& FalKow, S. (1984). Nucleotide sequence of the papA gene encoding the pap pilus subunit of human uropathogenic Escherichia coli. Journal of Bacteriology 157, 330-333.

BIRNBoim, H. C. \& Doly, J. (1979). A rapid alkaline extraction procedure for screening recombinant plasmid DNA. Nucleic Acids Research 7, 1513-1517.

Bolivar, F., Rodriguez, R. L., Greene, P. J., Betlach, M. C., Heynecker, H. L., Boyer, H. W., Crosa, J. H. \& Falkow, S. (1977). Construction and characterization of new cloning vehicles. II. A multipurpose cloning system. Gene 2, 95-113.

BRINTON, C. C. (1965). The structure, function, synthesis, and genetic control of bacterial pili and a model for DNA and RNA transport in Grarnnegative bacteria. Transactions of the New York Academy of Sciences 27, 1003-1054.

Chang, A. C. \& Cohen, S. N. (1978). Construction and characterization of amplifiable multicopy DNA cloning vehicles derived from the P15A cryptic miniplasmid. Journal of Bacteriology 134, 1141-1156.

ClegG, S. \& Pierce, J. K. (1983). Organization of genes responsible for the production of mannoseresistant fimbriae of a uropathogenic Escherichia coli isolate. Infection and Immunity 42, 900-906.

Duguid, J. P., Smith, I. W., Dempster, G. \& EDMunds, P. N. (1955). Non-flagellar filamentous appendages ('fimbriae') and haemagglutination activity in Bacterium coli. Journal of Pathology and Bacteriology 70, 335-348.

GaAstra, W. \& DE GraAF, F. K. (1982). Host-specific fimbrial adhesins of non-invasive enterotoxigenic Escherichia coli strains. Microbiological Reviews 46, 129-161. de GraAf, F. K., KrenN, B. E. \& KlaAsen, P. (1984). Organization and expression of genes involved in the biosynthesis of $\mathrm{K} 99$ fimbriae. Infection and Immunity 43, 508-514.

Korhonen, T. K., Eden, S. \& Svanborg Eden, C. $(1980 a)$. Binding of purified Escherichia coli pili to human urinary tract epithelial cells. FEMS Microbiology Letters 7, 237-240.

Korhonen, T. K., Nurmiaho, E.-L., Ranta, H. \& SVANBORG EDEN, C. $(1980 b)$. New method for isolation of immunologically pure pili from Escherichia coli. Infection and Immunity 27, 569-575.

Korhonen, T. K., LefFler, H. \& Svanborg Eden, C. (1981). Binding specificity of piliated strains of Escherichia coli and Salmonella typhimurium to epithelial cells, Saccharomyces cerevisiae cells, and erythrocytes. Infection and Immunity 32, 769-804.

Korhonen, T. K., VÄIsÄnen, V., SAXen, H., HultBERG, H. \& SVENSON, S. B. (1982). P-antigenrecognizing fimbriae from human uropathogenic Escherichia coli strains. Infection and Immunity 37, 286-291.

Korhonen, T. K., RHEN, M., VÄISÄNEN-Rhen, V. \& PERE, A. (1985a). Antigenic and functional properties of enterobacterial fimbriae. In Immunology of the Bacterial Cell Wall, pp. 319-353. Edited by D. E. S. Stewart-Tull \& M. Davies. Chichester: John Wiley \& Sons.

Korhonen, T. K., Valtonen, V. M., Parkkinen, J., VÄISÄNEN-RHEN, V., FINNE, J., ØRSKOV, F., ØRSKov, I., SVENSON, S. B. \& MäKELÄ, P. H. $(1985 b)$. Serotypes, hemolysine production, and receptor recognition of Escherichia coli strains associated with neonatal sepsis and meningitis. Infection and Immunity 48, 486-491.

LiNDBERG, F. P., LUND, B. \& Normark, S. (1984). Genes of pyelonephritogenic Escherichia coli required for digalactoside specific agglutination of human cells. EMBO Journal 3, 1167-1173.

Mandel, M. \& Higa, A. (1970). Calcium dependent 
bacteriophage DNA infection. Journal of Molecular Biology 53, 154-162.

Maniatis, T., Fritsch, E. F. \& SambrooK, J. (1982). Molecular Cloning : A Laboratory Manual. Cold Spring Harbor: Cold Spring Harbor Laboratory.

Messinger, J. \& Vieira, J. (1982). A new pair of M13 vectors for selecting either DNA strand of doubledigest restriction fragments. Gene 19, 269-276.

MooI, F. R., Harms, N., BAKKer, D. \& DE GRAaF, F. K. (1981). Organization and expression of genes involved in the production of the K88ab antigen. Infection and Immunity 32, 1155-1163.

Norgren, M., Normark, S., LaRK, D., O'Hanley, P., Schoolnik, G., Falkow, S., Svanborg Eden, C., BÅGA, M. \& UHLIN, B. E. (1984). Mutations in E. coli cistrons affecting adhesion to human cells do not abolish Pap pili fiber formation. EMBO Journal 3, 1159-1165.

Normark, S., Lark, D., Hull, R., Norgren, M., BÅga, M., O’Hanley, P., Schoolnik, G. \& FalKow, S. (1983). Genetics of a digalactoside binding adhesin from a uropathogenic Escherichia coli strain. Infection and Immunity 41, 942-948.

Nowicki, B., RHEN, M., VÄISÄNEN-RHEN, V., PERE, A. \& KORHONEN, T. K. (1984). Immunofluorescence study of fimbrial phase variation in Escherichia coli KS71. Journal of Bacteriology 160, 691-695.

Nowicki, B., Rhen, M., VÄISÄNen-RHen, V., Pere, A. \& Korhonen, T. K. (1985). Fractionation of a bacterial cell population by absorption to erythrocytes and yeast cells. FEMS Microbiology Letters 26, $35-40$.

ØRSKOV, I., ØRSKov, F. \& BIRCH-ANDERSEN, A. (1980). Comparison of Escherichia coli fimbrial antigen F7 with type-1 fimbriae. Infection and Immunity 27, 657666.

Ørskov, I., Ørskov, F., Birch-ANDERSEN, A., KANAMORI, M. \& SVANBORG EDEN, C. (1982). O, K, H, and fimbrial antigens in Escherichia coli associated with pyelonephritis and cystitis. Scandinavian Journal of Infectious Diseases, Supplementum 33, 18-25.

PORTER, R. R. (1959). The hydrolysis of rabbit gammaglobulin and antibodies with crystalline papain. Biochemical Journal 73, 119-126.

RHEN, M. (1985). Characterization of DNA fragments encoding fimbriae of the uropathogenic Escherichia coli strain KS71. Journal of General Microbiology 131, 571-580.

Rhen, M., Klemm, P., Wahlström, E., Svenson, S. B., Källenius, G. \& KoRhonen, T. K. (1983a). P-fimbriae of Escherichia coli: immuno- and protein-chemical characterization of fimbriae from two pyelonephritogenic strains. FEMS Microbiology Letters 18, 233-238.
Rhen, M., Knowles, J., Penttilä, M. E., Sarvas, M. \& Korhonen, T. K. (1983b). P-fimbriae of Escherichia coli: molecular cloning of DNA fragments containing the structural genes. FEMS Microbiology Letters 19, 119-123.

RHEN, M.,MÄKELÄ, P. H. \& KoRHONEN, T. K. (1983c). P-fimbriae of Escherichia coli are subjected to phase variation. FEMS Microbiology Letters 19, 267-271.

Rhen, M., VäIsÄnen-Rhen, V., Pere, A. \& KorHONEN, T. K. (1985a). Complementation and regulatory interaction between two cloned fimbrial gene clusters of Escherichia coli strain KS71. Molecular and General Genetics 200, 60-64.

Rhen, M., VAN Die, I., VÄISÄNen-Rhen, V. \& BERGMANS, H. $(1985 b)$. The nucleotide sequences of the genes encoding the KS71A and F7, fimbrial subunits of uropathogenic Escherichia coli. European Journal of Biochemistry 151, 573-577.

Roberts, J. A., Hardaway, K., KaAck, B., Fussel, E. N. \& Baskin, G. (1984). Prevention of pyelonephritis by immunization with P-fimbriae. Journal of Urology 131, 602-607.

Sanger, F., Nicklen, S. \& Coulson, A. R. (1977). DNA sequencing with chain terminating inhibitors. Proceedings of the National Academy of Sciences of the United States of America 74, 5463-5467.

SVANBorg EdEN, C. \& Hansson, H. A. (1978). Escherichia coli pili as possible mediators of attachment to human urinary tract epithelial cells. Infection and Immunity 21, 229-237.

VäIsänen, V., Elo, J., Tallgren, L. G., SiItonen, A., Mäkelä, P. H., Svanborg Eden, C., Källenius, G., Svenson, S. B., Hultberg, H. \& Korhonen, T. K. (1981). Mannose-resistant haemagglutination and $\mathbf{P}$ antigen recognition are characteristic of Escherichia coli causing primary pyelonephritis. Lancet ii, 1366-1369.

VÄISÄNEN-RHEN, V., Elo, J., VÄISÄNeN, E., SIITONEN, A., Ørskov, I., Ørskov, F., SVENSON, S. B., MÄKelä, P. H. \& Korhonen, T. K. (1984). Pfimbriated clones among uropathogenic Escherichia coli strains. Infection and Immunity 43, 149-155.

VAN Die, I. \& Bergmans, H. (1984). Nucleotide sequence of the gene encoding the $\mathrm{F} 7_{2}$ fimbrial subunit of an uropathogenic Escherichia coli strain. Gene 32, 83-90.

VAN Die, I., VAN Megen, I., Hoekstra, W. \& BergmaNs, H. (1984). Molecular organization of the genes involved in the production of $\mathrm{F} 7_{2}$ fimbriae, causing mannose resistant haemagglutination of a uropathogenic Escherichia coli O6:K2:H1:F7 strain. Molecular and General Genetics 194, 528-533. 